\title{
A giant on the ground: another large-bodied Atractus (Serpentes: Dipsadinae) from Ecuadorian Andes, with comments on the dietary specializations of the goo-eaters snakes
}

\author{
PAULO PASSOS ${ }^{1}$, AgUSTÍN SCANFERLA ${ }^{2}$, PAULO R. MELO- \\ SAMPAIO $^{1}$, JORGE BRITO ${ }^{3,4}$ and ANA ALMENDARIZ ${ }^{3}$ \\ ${ }^{1}$ Departamento de Vertebrados, Museu Nacional, Universidade Federal do Rio de \\ Janeiro, Quinta da Boa Vista, 20940-040 Rio de Janeiro, RJ, Brazil \\ ${ }^{2}$ CONICET, Instituto de Bio y Geociencias del NOA (IBIGEO), 9 de Julio 14 \\ (A4405BBB), 4405, Rosario de Lerma, Salta, Argentina \\ ${ }^{3}$ Museo de Historia Natural, Instituto de Ciencias Biológicas, Escuela Politecnica \\ Nacional, Av. Ladrón de Guevara, PB 17-01-2759, Quito, Ecuador \\ ${ }^{4}$ Instituto Nacional de Biodiversidad, Calle Rumipamba 341 y Av. de los Shyris, PB 17-07-8976, Quito, Ecuador
}

Manuscript received on December 4, 2017; accepted for publication on January 12, 2018

\begin{abstract}
How to cite: PASSOS P, SCANFERLA A, MELO-SAMPAIO PR, BRITO J AND ALMENDARIZ A. 2019. A giant on the ground: another large-bodied Atractus (Serpentes: Dipsadinae) from Ecuadorian Andes, with comments on the dietary specializations of the goo-eaters snakes. An Acad Bras Cienc 91:e 20170976. DOI 10.1590/00013765201820170976 .
\end{abstract}

\begin{abstract}
Body-size is significantly correlated with the number of vertebrae (pleomerism) in multiple vertebrate lineages, indicating that somitogenesis process is an important factor dictating evolutionary change associated to phyletic allometry and, consequently, species fitness and diversification. However, the role of the evolution of extreme body sizes (dwarfism and gigantism) remains elusive in snakes, mainly with respect to postnatal ontogeny in dietary preferences associated with evolution of gigantism in many lineages. We described herein a new species in the highly diversified and species-rich genus Atractus on the basis of four specimens from the southeastern slopes of the Ecuadorian Andes. The new species is morphologically similar and apparently closely related to two other allopatric giant congeners (A. gigas and A. touzeti), from which it can be distinguished by their distinct dorsal and ventral coloration, the number of supralabial and infralabial scales, the number of maxillary teeth, and relative width of the head. In addition, we discuss on the ontogenetic trajectories hypotheses and dietary specializations related to evolution of gigantism in the goo-eaters genus Atractus.
\end{abstract}

Key words: Atractus gigas, Atractus touzeti, dietary shift, goo-eater snakes, macrostomy, postnatal ontogeny.

\section{INTRODUCTION}

Body-size is among the most important species

Correspondence to: Paulo Passos

E-mail: ppassos@mn.ufrj.br / atractus@gmail.com

ORCid: http://orcid.org/0000-0002-1775-0970

* Contribution to the centenary of the Brazilian Academy of Sciences. attributes (depicting common ancestry and organismal function), being the key factor in generating ecological and genetic divergence (Peters 1983, LaBarbera 1986, Hanken and Wake 1993, Nagel and Schluter 1998, Schluter 2000), and is also correlated with increasing of extinction risk (Vilela et al. 2014). As such, the allometric 
change in time is a primary axis for diversification of many lineages, and can be important for dictating niche parameters, creating reproductive isolation, and structuring communities (Losos 1992, Nagel and Schluter 1998, Schluter 2000, Moen and Wiens 2008). Some lineages have experienced extreme, and often paradoxical - the occurrence of giant diggers when most of fossorial tetrapods tend to miniaturization, see Hanken and Wake (1993) — evolutionary change in body size (gigantism and dwarfism) due to colonizing new regions such islands or deep seas, re-colonization of mainland after mass extinctions, environmental shifts or stochastic evolutionary novelty (Bonnet et al. 2009 and references therein). The extrinsic factors (selective) responsible for the evolution of body size extremes in terrestrial vertebrates have been a recent topic of interest (Meik et al. 2010 and references therein), but the intrinsic mechanisms (developmental) underlying body size evolution still poorly understood and under dispute in the recent literature (Head and Polly 2015 and references therein).

Body size is significantly correlated with number of vertebrae (pleomerism) in multiple vertebrate lineages (Alexander and Gans 1966, Lindsey 1975, Lindell 1994, Müller et al. 2010, Head and Polly 2007), indicating that increasing body segments in the course of somitogenesis plays an important role in body size evolution (Lindell 1994). Snakes show greater variability in vertebral number than other amniotes (Müller et al. 2010, Head and Polly 2007). The axial regionalization is reduced in snakes by expansion of expressions domains for Hox genes that code for the dorsal region of the vertebral column, suppressing expression of a distinct cervical region (Cohn and Tickle 1999) or, by contrast, there is a retention of standard vertebrate Hox domains with alteration of downstream expression that suppresses development of distinct regions (Woltering 2012). Among snakes, gigantism is pronounced in the constrictor species of the families Boidae and Pythonidae, which forage through a sit-and-wait strategy and kill their prey by asphyxia due to strong body constriction (Henderson and Powell 2007). Although pleomerism has been established as an effective process to the body size evolution in snakes (Lindell 1994), only more recently the correlation between body size and developmental evolution (= somatic growth) of giant snakes was addressed using a phylogenetic framework (Meik 2010, Head and Polly 2007, 2015).

On the other hand, snakes are gape-limited predators that swallow their prey whole without mechanical reduction prior to prey ingestion, except for few very specialized Homalopsine snakes (see Jayne et al. 2002). As a rule, the basal lineages of snakes (e.g., Scolecophidians and Henophidians) occupying underground macrohabitats feed on small size prey, such as insects, earthworms and tiny elongate vertebrates; while alethinophidian snakes developed extreme anatomical adaptations (macrostomy) to ingest prey with large crosssection area in relation to their head dimensions. Remarkably, several clades of small cryptozoic macrostomatans reverse postnatal morphological transformations correlated with gape increasing to a phenotype constraining the diet to prey with low cross-section area (Scanferla 2016). However, it not clear how some lineages evolved and maintained gigantism while having diets specialized in prey with small size and low caloric value (Arnold 1993), as some mollusks and annelids in the case of Neotropical goo-eaters snakes (e.g., the genus Atractus).

Our aim in this study, beyond describing a new giant species from southeastern slopes of the Ecuadorian Andes, is to discuss some aspects related to postnatal ontogeny and dietary specialization found in the highly diversified and species-rich genus Atractus. 


\section{MATERIALS AND METHODS}

Specimens examined are deposited in the following collections: División de Herpetología del Museo Ecuatoriano de Ciencias Naturales (DHMECN), Instituto Nacional de Biodiversidad, Quito Ecuador; Museo de Historia Natural de la Escuela Politécnica Nacional (MEPN), Quito, Ecuador; Museo de Zoología, Pontificia Universidad Católica del Ecuador (QCAZ), Quito, Ecuador; and Fundación Herpetológica Gustavo Orcés (FHGO), Quito, Ecuador. Comparative material of Atractus gigas and Atractus touzeti is listed in Appendix I, while additional congeners examined are listed in Passos et al. (2005), Passos et al. (2007a, b), Passos and Fernandes (2008), Passos and Arredondo (2009), Passos et al. (2009a, b, c, d, e), Passos et al. (2010a, b, c), Passos and Lynch (2011), Passos and Prudente (2012), Passos et al. (2012), Prudente and Passos (2008, 2010), Passos et al. (2013a, b, c, d), Almeida et al. (2014), Salazar-Valenzuela et al. (2014), Passos et al. (2016a, b), de Fraga et al. (2017), and Passos et al. (2017). We provide the authorship and date only in the first mention of each name.

\section{GEOGRAPHICAL DATA}

Coordinates of localities were acquired in the field with Global Positioning System devices (referenced to map datum WGS84), and by consulting data in museum catalogues or databases. We refined, when possible, the provenance of records obtained from the literature or available in museum databases without specific field coordinates using the software Google Earth Pro 7.1.2 (Google 2005).

\section{TECHNIQUES AND CHARACTERS}

Terminology for cephalic shields follows Savage (1960) as augmented by Peters (1964), whereas ventral and subcaudal counts follow Dowling (1951). Condition of the loreal scale follows Passos et al. (2007b). Measurements were taken with a dial caliper (Mitutoyo ${ }^{\circledR}$ ) to the nearest $0.1 \mathrm{~mm}$, except for snout-vent length (SVL) and caudal length (CL), which were measured with a ruler to the nearest $1 \mathrm{~mm}$. Measurements and descriptions of paired cephalic scales are strictly based on the right side of head. We measure the head length from tip of rostral scale to the end of the quadratemandibular joint, head width in the broadest region and midbody diameter at mid-length of SVL. Counts of body marks (blotches, spots, and dots), in some taxa, were performed separately on each side of the dorsum because these marks are not always transversally continuous or equivalent along the sides of vertebral region. Herein, the term "blotch" refers to broader (two or more scales long and wide) dorsal marks located on the vertebral and paravertebral regions, the term "spot" refers to small (less than two scales long and wide) marks throughout the dorsum or venter, whereas "dot" refers to any mark smaller than a scale. The color tones follow Köhler (2012). Sex was determined on the basis of presence/absence of hemipenes verified through a ventral incision at the base of the tail. We examined maxillae in situ under a stereomicroscopy, through a narrow lateromedial incision between the supralabials and the maxillary arch. After removing tissues covering the maxillary bone, we counted teeth and empty sockets. We follow Passos et al. (2009e) and Passos et al. (2010c) with respect to conditions of the morphological characters used in diagnosis and description.

\section{RESULTS}

SPECIES DESCRIPTION

Atractus atlas sp. nov.

Atractus sp.-Almendáriz, Simmons, Brito y VacaGuerrero. 2014. Amphibian \& Reptile Conservation 8(1): 60 .

ZooBank Life Science Identifier (LSID): urn:1sid:zoobank.org:pub:3E2761FF-D4F1-4C2AA4D5-A7A54D7C0CDC 


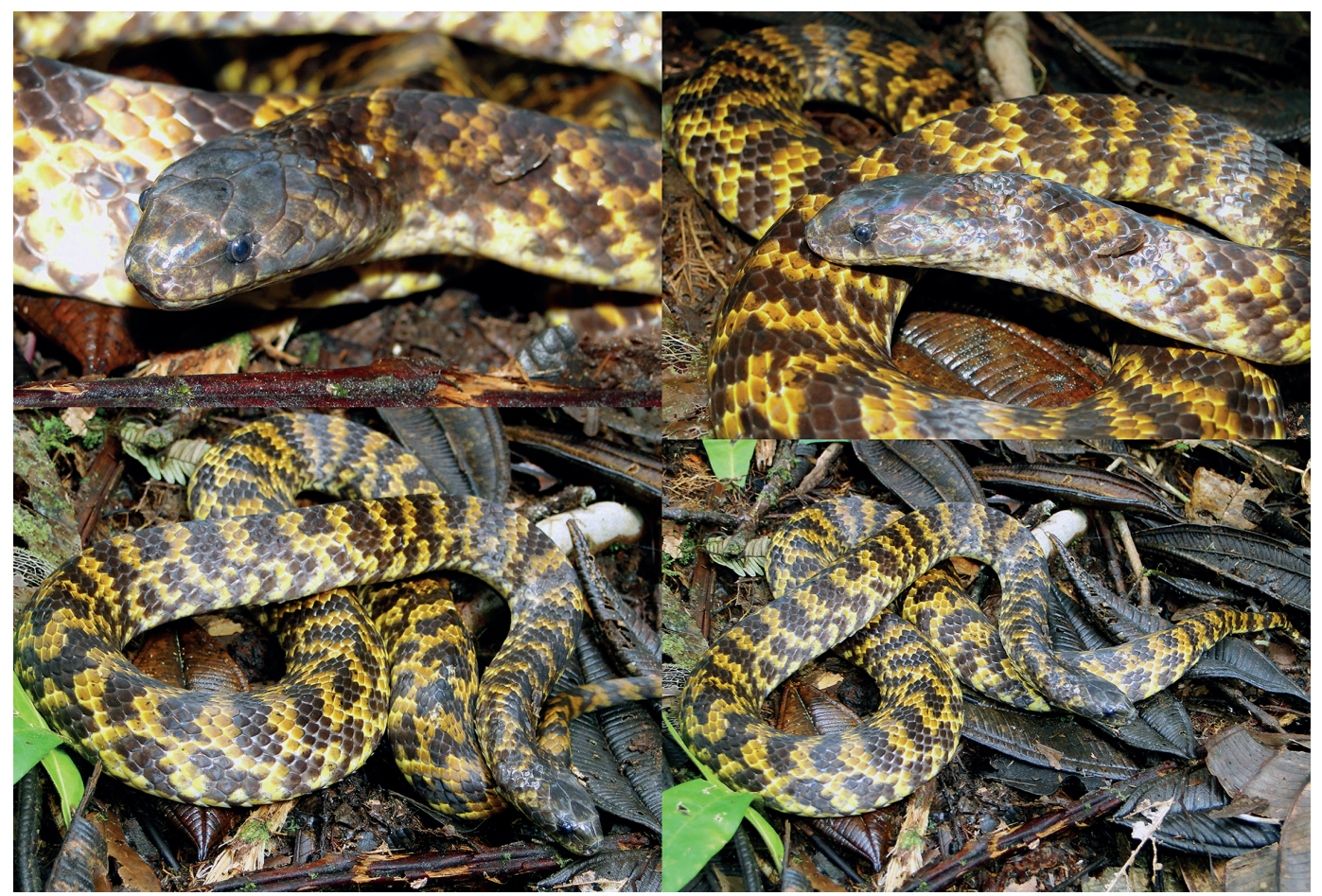

Figure 1 - General view in life of the holotype of Atractus atlas sp. nov. (MEPN 14203). SVL 820 mm, CL $106 \mathrm{~mm}+N$ (amputated tail).

\section{Holotype}

An adult female (MEPN 14203) collected on July 262011 by Ana Almendáriz, Jorge Brito, Juan Hurtado and Jorge Puchaicela at Rio Blanco (035'2.08"S 78³0'9.81'”W, ca. $1850 \mathrm{~m}$ above sea level; asl hereafter), Paquisha, municipality of Paquisha, province of Zamora-Chinchipe, Ecuador (Figs. 1-2).

\section{Paratypes}

Three adult females from southeastern slopes of Ecuadorian Andes: (DHMECN 2972) collected on May 2005 by Juan Carlos Ronquillo at Guayzimi Alto (0406'20.7'S 7846’05.7’W; ca. $2100 \mathrm{~m}$ asl ), Parroquía Guayzimi, province of ZamoraChinchipe; (QCAZ 14946) from Reserva Biológica Cerro Plateado (04³6'20's 7852'30'”W; ca. $1700 \mathrm{~m}$ asl), and (DHMECN 12361) collected on July 52014 by Jorge Brito and Victor León at Zúñac (02¹1'48”S 78¹8'58'”W; ca. 1900 m asl),
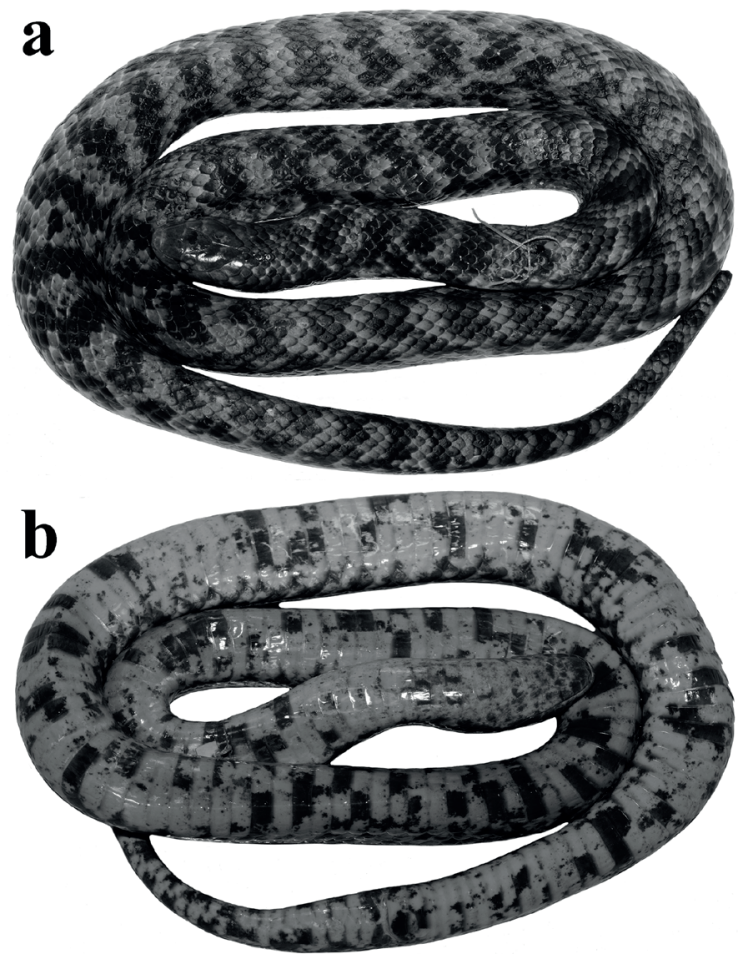

Figure 2 - Dorsal (a) and ventral (b) views of body of the holotype of Atractus atlas sp. nov. (MEPN 14203; SVL 820 $\mathrm{mm}, \mathrm{CL} 106 \mathrm{~mm}+N)$. 
TABLE I

Meristic and morphometric variation for the type-series of Atractus atlas sp. nov. and of Atractus touzeti, both comprising by females only. The " $\sim$ " represent the specimens for which the measurement was approximated according to their state of preservation or due to tail amputation.

\begin{tabular}{|c|c|c|c|c|c|c|c|}
\hline Features & $\begin{array}{c}\text { MEPN } 14203 \\
\text { holotype of } A \text {. } \\
\text { atlas }\end{array}$ & $\begin{array}{c}\text { DHMEC } \\
12361 \\
\text { paratype of } A . \\
\text { atlas }\end{array}$ & $\begin{array}{c}\text { DHMEC } \\
2972 \\
\text { paratype of } A . \\
\text { atlas }\end{array}$ & $\begin{array}{l}\text { QCAZ } 14946 \\
\text { paratype of } A . \\
\text { atlas }\end{array}$ & $\begin{array}{c}\text { FHGO } 517 \\
\text { holotype of } A . \\
\text { touzeti }\end{array}$ & $\begin{array}{c}\text { FHGO } 2035 \\
\text { paratype of } A . \\
\text { touzeti }\end{array}$ & $\begin{array}{c}\text { FHGO } 2036 \\
\text { paratype of } A . \\
\text { touzeti }\end{array}$ \\
\hline $\begin{array}{l}\text { Snout-vent } \\
\text { length } \\
\text { (SVL) }\end{array}$ & $820 \mathrm{~mm}$ & $700 \mathrm{~mm}$ & $735 \mathrm{~mm}$ & $\sim 635 \mathrm{~mm}$ & $1035 \mathrm{~mm}$ & $900 \mathrm{~mm}$ & $\sim 830 \mathrm{~mm}$ \\
\hline $\begin{array}{c}\text { Caudal } \\
\text { length }(\mathrm{CL})\end{array}$ & $106 \mathrm{~mm} *$ & $105 \mathrm{~mm}$ & $90 \mathrm{~mm}$ & $65 \mathrm{~mm} *$ & $118 \mathrm{~mm}$ & $115 \mathrm{~mm}$ & $112 \mathrm{~mm}$ \\
\hline $\mathrm{SVL} / \mathrm{CL}$ & $\sim 12.9$ & 15 & 12.2 & $\sim 10.2$ & 11.4 & 12.8 & $\sim 13.5$ \\
\hline Head length & $34.4 \mathrm{~mm}$ & $26.9 \mathrm{~mm}$ & $27.8 \mathrm{~mm}$ & $25.1 \mathrm{~mm}$ & $41.0 \mathrm{~mm}$ & $35.9 \mathrm{~mm}$ & $36.5 \mathrm{~mm}$ \\
\hline Head width & $17.4 \mathrm{~mm}$ & $16.6 \mathrm{~mm}$ & $14.5 \mathrm{~mm}$ & $12.4 \mathrm{~mm}$ & $27.2 \mathrm{~mm}$ & $26.0 \mathrm{~mm}$ & $25.4 \mathrm{~mm}$ \\
\hline $\begin{array}{l}\text { Midbody } \\
\text { diameter }\end{array}$ & $18.3 \mathrm{~mm}$ & $18.1 \mathrm{~mm}$ & $21.4 \mathrm{~mm}$ & $18.0 \mathrm{~mm}$ & $28.3 \mathrm{~mm}$ & $23.0 \mathrm{~mm}$ & $22.4 \mathrm{~mm}$ \\
\hline Supralabials & 8 & 8 & 8 & 8 & 8 & 8 & 8 \\
\hline Infralabials & 8 & 8 & 8 & 8 & $8 / 7$ & 8 & 8 \\
\hline $\begin{array}{l}\text { Infralabials- } \\
\text { chinshields }\end{array}$ & 4 & 4 & 4 & 4 & $4 / 3$ & 4 & 4 \\
\hline Preventrals & 3 & 4 & 4 & 4 & 4 & 3 & 4 \\
\hline Ventrals & 169 & 168 & 162 & 158 & 172 & 170 & 168 \\
\hline Subcaudals & $31 / 31 *$ & 33 & $28 / 28$ & $24 / 25^{*}$ & $30 / 31$ & $31 / 32$ & $30 / 31$ \\
\hline $\begin{array}{c}\text { Gular scale } \\
\text { rows }\end{array}$ & 3 & 4 & 4 & 4 & 4 & 4 & 4 \\
\hline $\begin{array}{c}\text { Maxillary } \\
\text { teeth }\end{array}$ & 8 & 8 & 8 & 8 & 8 & 8 & 8 \\
\hline
\end{tabular}

* Represents the specimens for which its tail was partially amputated.

Parque Nacional Sangay, Cantón Morona, both in the province of Morona Santiago. Quantitative variation of the type-series of Atractus atlas is presented in Table I.

\section{Diagnosis}

Atractus atlas can be distinguished from all congeners by the following combination of characters: (1) smooth dorsal scale rows 17/17/17; (2) postoculars two; (3) loreal moderately long, contacting second to fourth supralabials; (4) temporal formula usually $1+2$; (5) supralabials eight, fourth and fifth contacting eye; (6) infralabials eight, first four contacting chinshields; (7) maxillary teeth eight; (8) gular scale rows usually four; (9) preventrals usually four; (10) ventrals 158-169 in females; (11) subcaudals 2833 in females; (12) in preservative, dorsum yellow ocher with a series of alternating black bands (2-3 scales long), connected or not to the opposite band on the vertebral region; (13) ventral surface of body mostly pale buff scattered with conspicuous black marks (blotches, spots and dots); (14) maximum body size moderate in females $820 \mathrm{~mm} \mathrm{SVL}$; (15) tail size moderately long in females (12.2-15.0\% SVL); (16) midbody diameter in females 18.0-21.4 $\mathrm{mm}$.

\section{Comparisons}

Among all congeners, Atractus atlas is similar to A. gigas Myers and Schargel 2006, A. serranus Amaral 1930, A. torquatus Duméril, Bibron and Duméril 1854, A. touzeti Schargel et al. 2013, and 

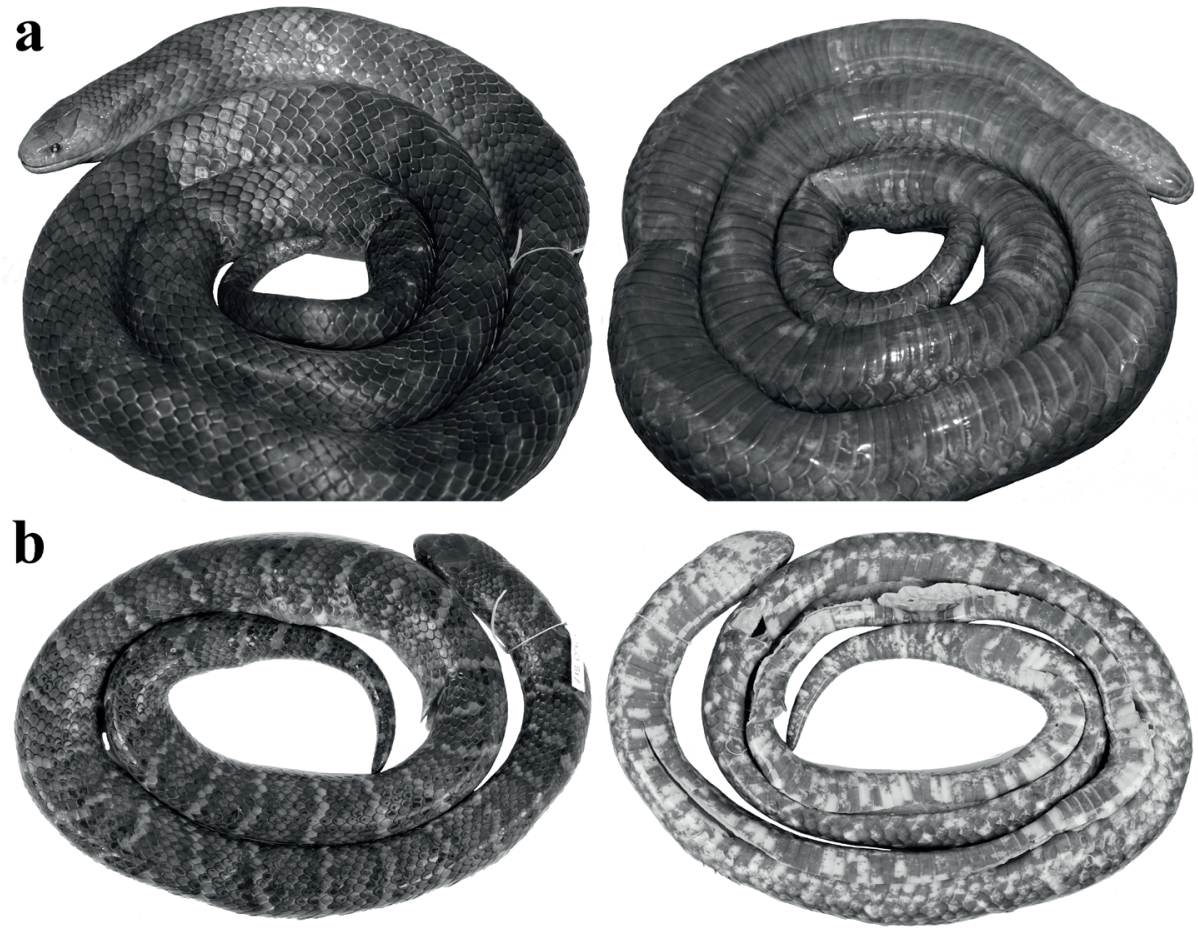

Figure 3 - Dorsal (left) and ventral (right) views of body of the paratype of Atractus atlas (DHMECN 2972 - A, SVL $735 \mathrm{~mm}$, CL $90 \mathrm{~mm}$ ) and the holotype of Atractus touzeti (FHGO 517 - B; SVL $1035 \mathrm{~mm}$, CL $118 \mathrm{~mm}$ ).

A. trihedrurus Amaral 1926 in having: SVL $>600$ $\mathrm{mm}$, midbody diameter $>18.0 \mathrm{~mm}$, dorsal scales rows 17/17/17, supralabials and infralabials eight, postoculars two, maxillary teeth eight, dorsum with banded pattern, and ventral surface of body light with several black marks or mostly black. Atractus atlas differs from all of them except for A. torquatus and $A$. touzeti in having a banded dorsum in adult specimens (vs. adults uniformly greyish brown to black in A. gigas, A. serranus and A. trihedrurus); from A. torquatus in having two postoculars, 28-33 subcaudals in females, and ventral surface of body mostly darker or heavily marked with irregular black blotches (vs. usually one postocular, subcaudals 3447 , and belly mostly creamish white scattered with dark brown dots or irregular rhomboidal spots); from A. touzeti in having head width $<55 \%$ head length and dorsum with a series of alternating dark brown to black bands (2-3 scales long), connected or not to the opposite band on the vertebral region (vs. head width $>66 \%$ head length and dorsum with tiny pale cross-bands [one scale long] edged by black borders [half to one scale long], separating the pale color from the brown ground color). Moreover, Atractus atlas differs from $A$. gigas in having eight supra- and infralabials, second to fourth supralabials contacting loreal, fourth to fifth supralabials contacting eye, first four infralabials contacting chinshields (vs. supra- and infralabials usually seven, second and third infralabials contacting loreal, third to fourth supralabials contacting eye, first three infralabials contacting chinshield) (Fig. 4). In addition, we refer to Table I for other diagnostic features of the $A$. atlas with respect to A. touzeti, and to comparisons with other congeners for which we have recorded specimens above $500 \mathrm{~mm}$ SVL (see Passos et al. 2010a, Table I).

\section{Description of the holotype}

Adult female, SVL $820 \mathrm{~mm}$, CL $106 \mathrm{~mm}+n$ (partially amputated tail) (12.9\% SVL); head 

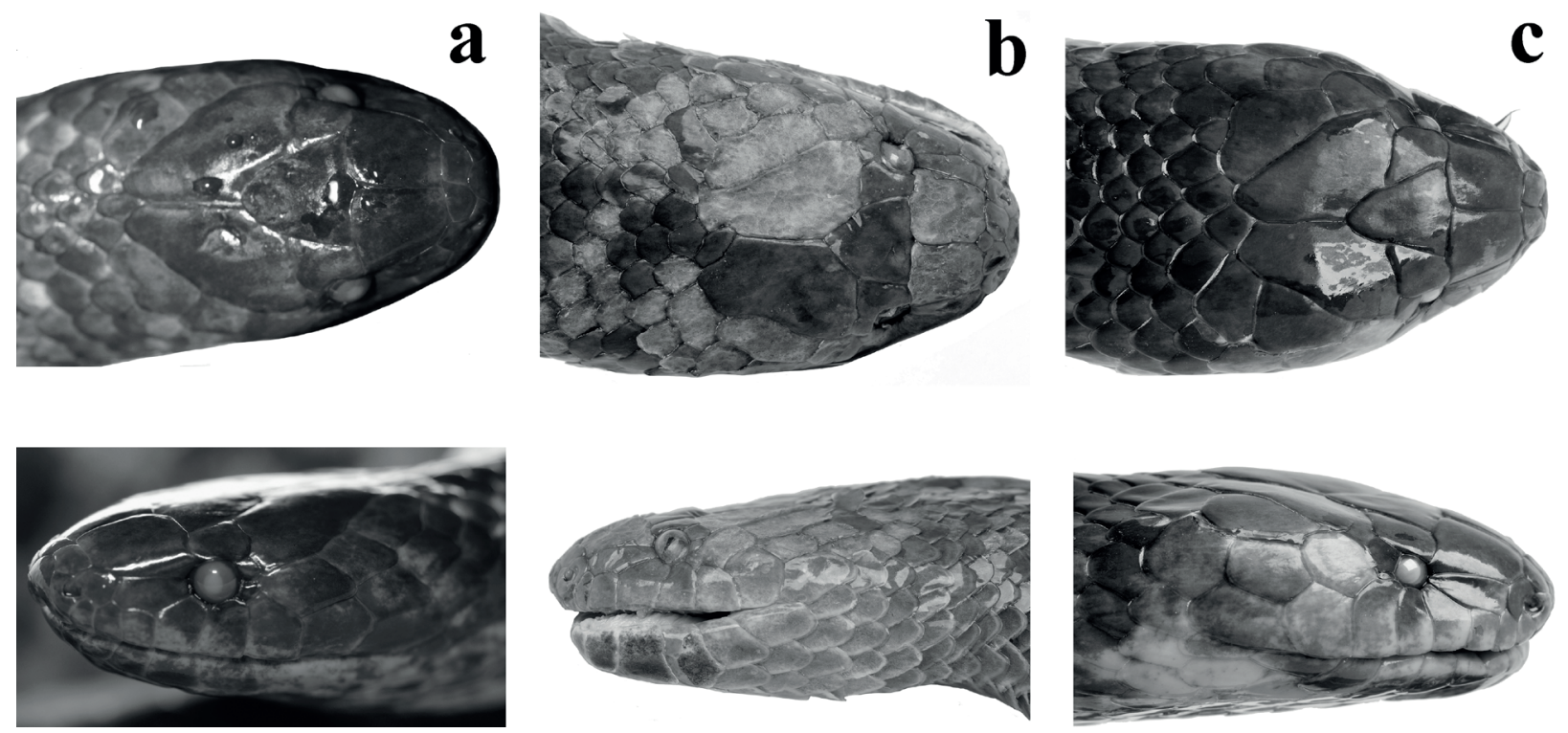

Figure 4 - Heads in dorsal (top) and lateral (bottom) views of the holotypes of Atractus atlas (MEPN 14203 - a, SVL 820 mm, CL $106 \mathrm{~mm}+$ N), Atractus gigas (FHGO 194 - b, SVL 890 mm, CL 120 mm), and Atractus touzeti (FHGO 517 - c, SVL 1035 mm, CL $118 \mathrm{~mm})$.

slightly distinct from body; head length 34.4 $\mathrm{mm}$ (4.2\% SVL); head width $17.4 \mathrm{~mm}(50.1 \%$ head length); head height $12.2 \mathrm{~mm}$; rostral-orbit distance $10.1 \mathrm{~mm}$; nasal-orbit distance $8.4 \mathrm{~mm}$; interorbital distance $11.9 \mathrm{~mm}$; head flattened in lateral view; snout anteriorly slightly depressed and truncate in lateral view, rounded in dorsal view; canthus rostralis conspicuous to eye level; rostral subtriangular in frontal view, $4.9 \mathrm{~mm}$ wide, $4.4 \mathrm{~mm}$ high, slightly visible in dorsal view; internasal 2.7 $\mathrm{mm}$ long, $1.6 \mathrm{~mm}$ wide; internasal suture sinistral with respect to prefrontal suture; prefrontal $6.1 \mathrm{~mm}$ long, $6.0 \mathrm{~mm}$ wide; supraocular sub-rectangular, $4.2 \mathrm{~mm}$ long, $3.3 \mathrm{~mm}$ wide at broadest point; frontal subpyramidal, $7.7 \mathrm{~mm}$ long, $6.9 \mathrm{~mm}$ wide; parietal $11.7 \mathrm{~mm}$ long, $6.9 \mathrm{~mm}$ wide; nasal entirely divided, nostril restricted to prenasal; prenasal 2.9 $\mathrm{mm}$ high, $1.6 \mathrm{~mm}$ long; postnasal $2.4 \mathrm{~mm}$ high, $2.0 \mathrm{~mm}$ long; loreal $5.2 \mathrm{~mm}$ long, $2.2 \mathrm{~mm}$ high; second, third and fourth supralabials contacting loreal; eye diameter $3.7 \mathrm{~mm}$; pupil rounded; two postoculars similar in length; upper postocular 1.4 mm long, $2.1 \mathrm{~mm}$ high; lower postocular narrowing ventrally, $1.0 \mathrm{~mm}$ long, $1.4 \mathrm{~mm}$ high; temporal formula 1+2; first temporal $5.8 \mathrm{~mm}$ long, $3.0 \mathrm{~mm}$ high; three upper posterior temporals not fused, larger $6.3 \mathrm{~mm}$ long, $3.6 \mathrm{~mm}$ wide; supralabials eight, fourth and fifth contacting eye; first three supralabials with similar height, fourth and sixth supralabials taller $\left(6^{\text {th }} 4.6 \mathrm{~mm}\right.$ high $/ 3.1 \mathrm{~mm}$ long $)$ and eighth longer (5.8 $\mathrm{mm}$ long/2.5 $\mathrm{mm}$ high) than remaining supralabials; symphysial semicircular, $3.0 \mathrm{~mm}$ wide, $1.0 \mathrm{~mm}$ long; first pair of infralabials preventing symphysial-chinshields contact; infralabials eight, first four contacting chinshields; chinshields $8.7 \mathrm{~mm}$ long, $4.1 \mathrm{~mm}$ wide; gular scale rows three; preventrals three; ventrals 169; subcaudals 31 left/ 31 right $+n$ (partially amputated tail); dorsal scale rows $17 / 17 / 17$, lacking apical pits and supracloacal tubercles; midbody diameter 18.3 $\mathrm{mm}(2.2 \% \mathrm{SVL})$; tail lacking caudal spine.

In life, dorsum of head mostly black suffused with pale greenish yellow pigmentation (by diffuse irregular dots) covering cephalic shields on the snout region (rostral, internasals and mainly anterior region of preferontals); lateral surface 
of head black, extending to end of parietals and adjacent dorsal scales; lateral scales of head black with pale greenish yellow pigments above anterior (nasals and anterior portion of loreal) and posterior (mainly posterior temporals) regions; supralabials mostly black, except for the lower half portions (diagonally marked) of first five or six scales (only ventral margin) pale greenish yellow; lateral sides of head on the occipital region with barely defined descending postorbital medium greenish yellow stripe, extending from posterior temporal scales to mouth rictus; infralabials and gular region mostly black with pale greenish yellow spots on the posterior portion of chinshields and from sixth to eight infralabials; last three infralabials and remaining scale on the gular region scarcely marked with dispersed black dots or spots; ventral surface of body pale greenish yellow with few dispersed black dots, spots and large rectangular blotches (occupying half to almost entire surface of ventral scale); ventral surface of tail predominantly pale greenish yellow with black blotches (one or two scales long) concentrated laterally; dorsal ground color of body medium greenish yellow with 48 conspicuous black transversal blotches (two or three scales long) usually connected on the vertebral region but asymmetrical with respect to paraventral blotches or posts (one or two scales long); dorsal blotches forming irregular cross-bands frequently interrupted on the level of fifth scale rows flanks (= paraventral region); blotches laterally (extending for first fourth to fifth series of scales) isolated from dorsal blotches or connected to one or two dorsal marks, giving impression of an alternating or barely defined zigzag pattern; interspaces between black paraventral blotches on the first two scales rows lighter (pale greenish yellow); dorsal surface of tail with pattern similar of body, medium greenish yellow background with 11 black cross-bands (one or two scales long), reaching paraventral region (Fig. 1). After preservation in $70 \%$ ethanol, dorsal ground color of head jet black with pale buff pigments covering labial border and gular region; dorsum of body mostly dark spectrum yellow with black marks (blotches, spots or dots), with cream white spots on the paraventral region; ventral surface of belly and tail pale buff with olive brown marks (Fig. 2).

Color pattern variation in preservative: Dorsum of head sepia (DHMECN 2972) to jet black (DHMECN 12361), with beige (DHMECN 2972) to bunting green (DHMECN 12361) pigments covering labial and/or gular regions; ventral surface of body and tail pale greenish yellow with black marks (MEPN 14203) to cinnamon brown with few pale buff irregular spots (DHMECN 2972); dorsal ground color of body medium greenish yellow (MEPN 14203), tawny olive (DHMECN 2972) or cinnamon (DHMECN 12361) with 4648 rich red (DHMECN 2972) to jet black (MEPN 14203 ) cross-bands (two to three scales long on the vertebral region); blotches on the paraventral region regular and connected to dorsal cross-bands (DHMECN 2972) or fragmented into irregularly distributed and isolated paraventral blotches (MEPN 14203) (Figs. 2-3a).

Etymology: The Latinized specific epithet "atlas" ('A $\tau \lambda \alpha \varsigma)$ represents a Titan from the Greek mythology that was condemned by Zeus to support the entire world (or the heaven in some variations of the ancient legend) forever on their shoulders as punishment for attacking the Mount Olympus. The legend is also related to excess of obligations and duties or the huge efforts to complete certain difficult tasks. We employed herein this name alluding to the large body-size of the new species (it is among the five species of the genus that reach the largest body-size; see Passos et al. 2010a), as well as in reference to the tremendous endeavor for attaining the real diversity of Atractus, not only for discovering undescribed species, but also for recognition of a lot of synonymies in the old and even recent literature, or frequent species misidentifications in collections and public 


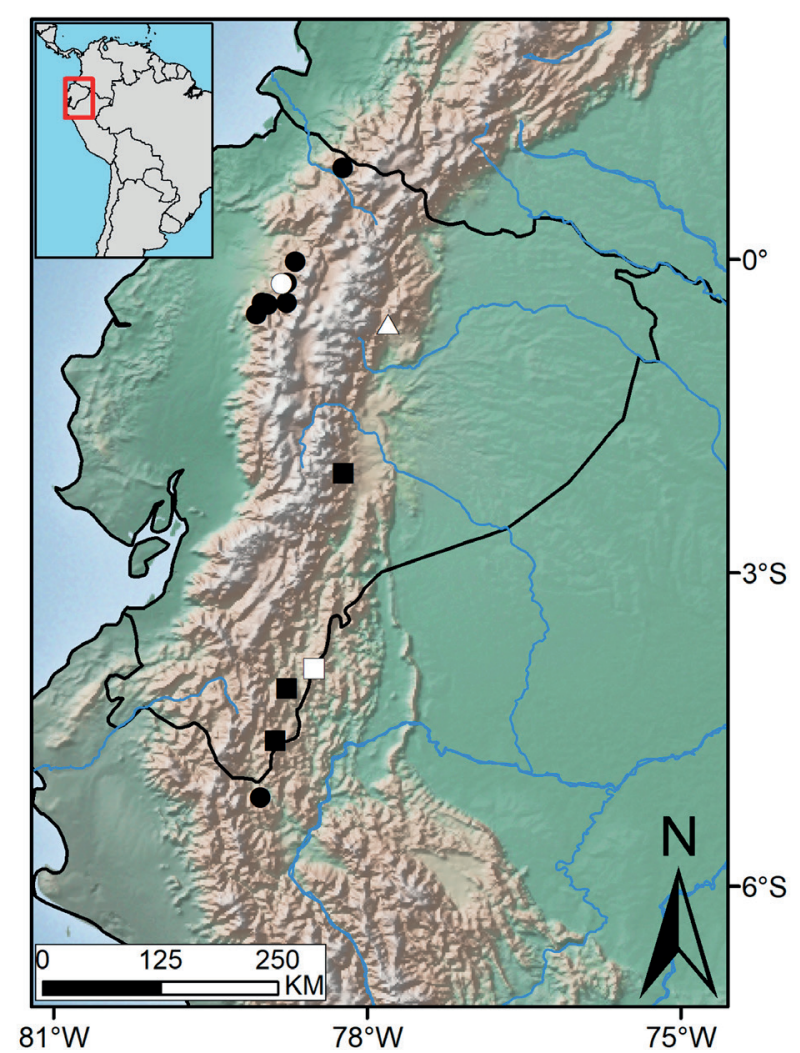

Figure 5 - Known distribution of Atractus atlas (squares), Atractus gigas (dots), and Atractus touzeti (triangles). Each type-locality is represented by open symbols. We did not include the new record of $A$. touzeti provided by Arteaga et al. (2017) because the identification of this specimen was not checked personally by us.

repositories (see Passos et al. 2017). We propose the vernacular name of Atractus atlas to be 'Atlas Ground Snake' in English and 'Culebra Tierrera del Atlas' in Spanish.

\section{Distribution and natural history}

Southeastern portions of Ecuadorian Andes, from Zúñac in the province of Morona Santiago, south to Paquisha, Guayzimi Alto and Reserva Biológica Cerro Plateado in the province of ZamoraChinchipe. Atractus atlas occurs in Mountain rainforest at 1800-2100 $\mathrm{m}$ asl (Fig. 5).

The holotype (MEPN 14203) was found resting under leaf litter locally called "bamba" at 10:46 am during thermoregulatory activity with direct incidence of sunlight. The vegetation covering the type-locality is composed by a type of cloud forest denominated "Western Mountain Forest". This forest formation usually remains cloudy in the early hours of the morning, afternoons, or even all day long, depending on the season, and is comprised by trees of 15-20 m covered with bryophytes, bromeliads and abundant moss. The plant layer sits on a plateau of sandstone, and grows on a substrate of very acid sand soil poor in nutrients.

The paratype (DHMECN 12361) is a roadkill found in the early hours of the morning dead on the Macas-Riobamba road. The vegetal formation in this locality is characterized as a premontane evergreen forest of the southern portion of Cordillera Oriental of the Ecuadorian Andes (Ministerio del Ambiente 2013), in which the trees have abundant orchids and bromeliads and the tree canopy reaches $30 \mathrm{~m}$ where the dominant trees species are romerillo (Prumnopitys montana), cedro (Cedrela montana) and royal palm (Dictyocaryum lamarckianum).

\section{DISCUSSION}

Macrostomatan snakes that exploit surface macrohabitats experiment an allometric elongation of the gnathic complex with respect to the rest of the skull and a backward rotation of the quadrate during postnatal ontogeny (Cundall and Greene 2000, Scanferla 2016), which permits the consumption of a wide array of bulky vertebrate prey with a high cross-sectional area. Notably, macrostomatans that exploit underground macrohabitats reverse this condition and return to a diet based on small prey with low cross-sectional area such as annelids, insects or elongated vertebrates. The dipsadine colubroids of the genus Atractus represent a typical group of underground-dweller snakes in which this ontogenetic trajectory reverses, displaying a short gnathic complex and an almost vertical quadrate in adult individuals (Cundall and Irish 2008). Available diet analyses of Atractus species show 


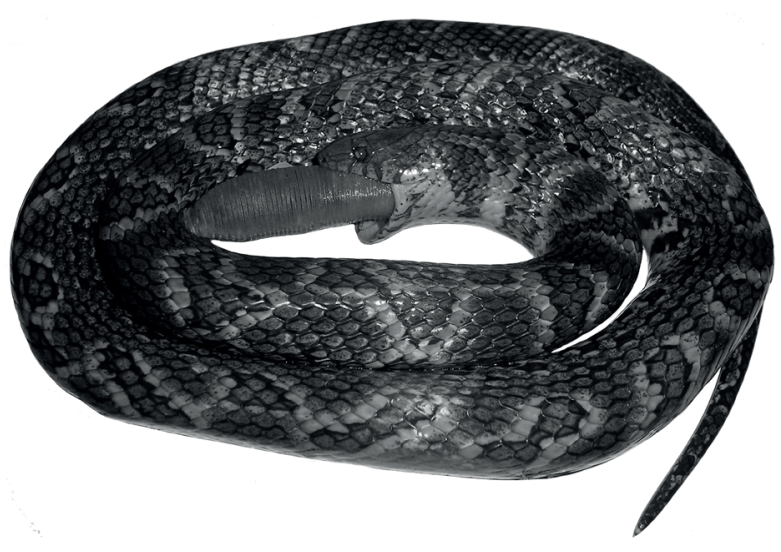

Figure 6 - A female specimen of Atractus major (MEPN 5146, SVL $745 \mathrm{~mm}$, CL $100 \mathrm{~mm}$ ) preserved with an individual of Oligochaeta (family Glossoscolecidae) on their mouth.

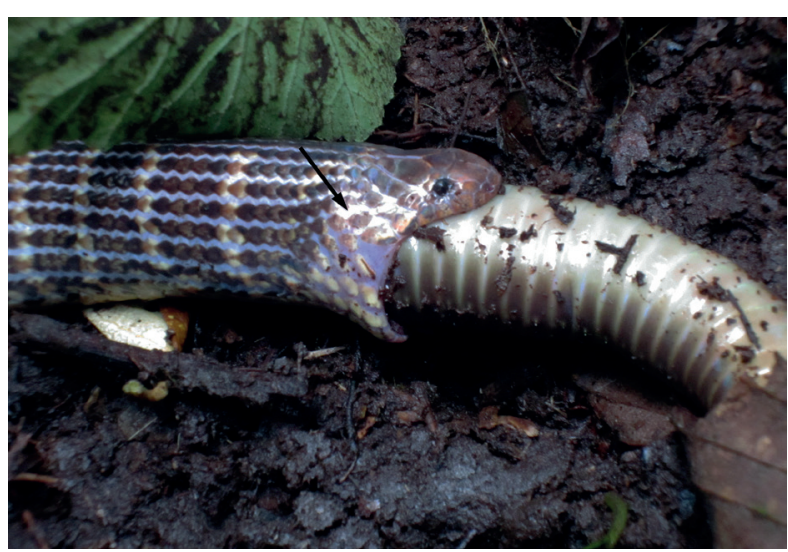

Figure 7 - General view of an uncollected specimen of Atractus sp. eating an earthworm in the field at Parque Nacional Sangay (02॰04'27.5”S, 78॰12'46.6”W; $1785 \mathrm{~m}$ asl), province of Morona Santiago, Ecuador. This specimen had about $750 \mathrm{~mm}$ of total length. Black arrow indicates the quadrate-mandibular joint displaced backward during swallowing process. Photo by Hérnan Orellana.

a predominantly lumbricophagous diet (Dixon et al. 1976, Martins and Oliveira 1999, Balestrin et al. 2007, Perrella and Francisco 2016), compatible with the anatomy of gnathic complex (sensu Cundall and Greene 2000). Despite there is a single report of a putative large-bodied Atractus with a snake and gymnophtalmid lizard in their stomachs (Pérez-Santos and Moreno 1990), the identification of these predators must be checked in detail because there are many specimens of Xenopholis and Rhadinaea misidentified as Atractus in several herpetological collections (P. Passos pers. obs.). Therefore, until a specialist in this group corroborates this report, we still consider the species of the genus Atractus as goo-eater specialists (see Cundall and Greene 2000 and Zaher et al. 2014 for other dietary specializations of goo-eaters snakes).

Interestingly, large species of Atractus (adults with SVL $>500 \mathrm{~mm}$ ) reacquired the elongation of the gnathic complex and the rotation of the quadrate bone in the same way that is present in surface-dweller macrostomatans. One example of this is Atractus major, a large species in which adult individuals display long palatomaxillary bars and lower jaws that surpass the posterior region of the skull, and a quadrate bone rotated backwards (Fig. 6 and Ramos 2017). The increase in gape size as a consequence of this postnatal ontogenetic trajectory seems to be not followed by a shift in the type of prey, because the scarce information on diet of large forms of Atractus indicates the same lumbricophagous diet observed in small species (Fig. 7). However, it is important to underline the scarce knowledge about diet preferences in Atractus. Among the impressive species diversity of the genus Atractus, there are several distantly related forms with large body size (see Table I from Passos et al. 2010a), which indicates that large body-size was acquired several times independently (Passos P., unpublished data). Taking into account that only large species of Atractus reacquired the skeletal requirements for macrostomy during their postnatal growth, then body-size appears to have had a central role in the reacquisition of this postnatal ontogenetic trajectory. If this is the case, the plasticity of this ontogenetic trajectory-on both extremes of developmental pathways - could represent a relevant key innovation to explain the impressive diversity and species richness of the neotropical genus Atractus. On other hand, the liability of the ontogenetic trajectory perhaps would be also relevant for increasing the fitness 
(sensu Arnold 1993) of miniaturized lineages, such the Amazonian Atractus collaris species group (Passos et al. 2013c), in which the main food resource along its range of distribution may be the small-sized species of the family Enchyathreidae (Oligochaeta, Annelida) (Bevilacqua 2014).

\section{ACKNOWLEDGMENTS}

The senior author thanks Jorge Valencia (FHGO), David Salazar-Valenzuela (MZUTI) Omar Torres-Carvajal (QCAZ), and Mario YanezMuñoz (DHMEC) for allowing the examination of the specimens under their care. Paulo Passos is deeply indebted with Omar Torres-Carvajal for workspace in the QCAZ, facilities for borrowing material from another Ecuadorian collections and providing high-resolution images from the typeseries of Atractus gigas and Atractus touzeti. We are grateful to Hérnan Orellana for providing live photos from Atractus sp. eating the earthworm, Renan M. Oliveira for the help with the distribution map, and two anonymous reviewers by helpful suggestions that improve the final version of the manuscript. Paulo R. Melo Sampaio thanks Yerka Sagredo for measurements of QCAZ specimen and help in Quito. Financial support for Paulo Passos was provided by Conselho Nacional de Desenvolvimento Científico e Tecnológico (CNPq) and Fundação Carlos Chagas Filho de Amparo à Ciência do Estado do Rio de Janeiro (FAPERJ); for Agustin Scanferla was provided by Consejo Nacional de Investigaciones Científicas y Técnicas (CONICET, PIP 2014-497). Kinross and CardnoEntrix Corporation provided financial support for the fieldwork of Ana Almendariz and Jorge Brito at Paquisha. The collections were made with the authorizations $\mathrm{N}^{\circ}$. 026-IC-FAU-DBAP-VSDRLZCH-MA and $\mathrm{N}^{\circ}$. 05-2014-I-B-DPMS/MAE granted by the Ministerio del Ambiente of Zamora Chinchipe and Morona Santiago, Ecuador. Paulo R. Melo Sampaio is a fellow funded by Coordenação de Aperfeiçoamento de Pessoal de Nível Superior (CAPES).

\section{REFERENCES}

ALEXANDER AA AND GANS C. 1966. The pattern of dermal-vertebral correlation in snakes and amphisbaenians. Zool Mededelingen 11: 171-190.

ALMEIDA PC, FEITOSA DT, PASSOS P AND PRUDENTE ALC. 2014. Morphological variation and taxonomy of the Atractus latifrons (Günther, 1868) (Serpentes: Dipsadidae). Zootaxa 3860: 64-80.

ARNOLD SJ. 1993. Foraging theory and prey-size-predatorsize relations in snakes. In: Seigel RA AND Collins JT (Eds), Snakes ecology and behavior, New Jersey: The Blackburn Press, p. 87-115.

ARTEAGA A, MEBERT K, VALENCIA JH, CISNEROSHEREDIA D, PEÑAFIEL N, REYES-PUIG C, VIEIRAFERNANDES J AND GUAYASAMIN JM. 2017. Molecular phylogeny of Atractus (Serpentes, Dipsadidae), with emphasis on Ecuadorian species and description of three new taxa. ZooKeys 661: 91-123.

BALESTRIN RL, DI-BERNARDO M AND MORENO AG. 2007. Feeding ecology of the netropical worm snakes Atractus reticulatus in southern Brazil. Herpetol J 17: 6264.

BEVILACQUA MS. 2014. Oligochaeta em riachos (igarapés) da Floresta Nacional de Saracá-Taquera (PA): abundância, riqueza, diversidade e potencial como indicador de impacto antrópico. MSc. Dissertation, Macaé: Universidade Federal do Rio de Janeiro, Brazil, 71 p. (Unpublished).

BONNET RM, CHIPPNDALE PT, MOLER PE, VAN DEVENDER RW and WAKE D. 2009. Evolution of gigantism in amphiumid salamanders. Plos One 4(5): e5617.

COHN MJ AND TICKLE C. 1999. Developmental basis of limblessness and axial patterning in snakes. Nature 399: 474-479.

CUNDALL D AND GREENE HW. 2000. Feeding in snakes. In: Schwenk K (Ed), Feeding: form, function, and evolution in tetrapod vertebrates. San Diego: Academic Press, 293-333 p.

CUNDALL D AND IRISH F. 2008. The snake skull. In: Gans C, Gaunt AS and Adler K (Eds), Biology of Reptilia Vol. 20, The Skull of Lepidosauria. New York: Society for the Study of Amphibians and Reptiles Press, 349-692 p.

DE FRAGA R, ALMEIDA AP, MORAES LJCL, GORDO M, PIRANI R, ZAMORA RR, CARVALHO VT, PASSOS P AND WERNECK FP. 2017. Narrow endemism or insufficient sampling? Geographic range extension and morphological variation of the poorly known Atractus riveroi Roze, 1961 (Serpentes: Dipsadidae). Herpetol Rev 48(2): 281-284. 
DIXON, JR, THOMAS RA AND GREENE HW. 1976. Status of the Neotropical snake Rhabdosoma poeppigi Jan, with notes on variation in Atractus elaps (Günther). Herpetologica 32(2): 221-227.

DOWLING HG. 1951. A proposed standard system of counting ventrals in snakes. British J Herpetol 1(2): 97-99.

GOOGLE. 2005. http://www.google.com/about/corporate/ company/history.html\#2005. (Accessed on 20 October 2017).

HANKEN J AND WAKE DB. 1993. Miniaturization of body size: organismal consequences and evolutionary significance. Annu Ecol Syst 24: 501-519.

HEAD JJ AND POLLY DP. 2007. Dissociation of somatic growth from segmentation drives gigantism in snakes. Biol Lett 3: 296-298.

HEAD JJ AND POLLY DP. 2015. Evolution of the snake body form reveals homoplasy in amniote Hox gene function. Nature 520: 86-89.

HENDERSON BW AND POWELL R. 2007. Biology of the Boas and Pythons. Singapore: Eagle Mountain Publishing, $438 \mathrm{p}$.

JAYNE BC, VORIS HK AND NG PKL. 2002. Snakes circumvents constraints on prey size. Nature 418: 143.

KÖHLER G. 2012. Color catalogue for field biologists. Affenbach: Herpeton, 49 p.

LABARBERA M. 1986. The evolution and ecology of body size. In: Raup DM and Jablonski D (Eds), Patterns and processes in the history of life: Berlin: Springer-Verlag, Berlin Germany, p. 69-98

LINDELL LE. 1994. The evolution of vertebral number and body size in snakes. Funct Ecol 8: 708-719.

LINDSEY CC. 1975. Pleomerism, the widespread tendency among related fish species for vertebral number to be correlated with maximum body length. J Fish Res Board Can 32: 2453-2469.

LOSOS JB. 1992. The evolution of convergence community structure in Caribbean Anolis communities. Systematic Biol 41: 403-420.

MARTINS M AND OLIVEIRA ME. 1999. Natural history of snakes in forests of the Manaus region, Central Amazônia, Brazil. Herpol Nat Hist 6: 78-150.

MEIK, JM, LAWING AM AND PIRES-DA-SILVA A. 2010. Body size evolution in insular Speckled rattlesnakes (Viperidae: Crotalus mitchelli). Plos One 5(3): e9524.

MINISTERIO DEL AMBIENTE. 2013. Sistema de clasificación de los ecosistemas del Ecuador continental. Quito: Ministerio del Ambiente del Ecuador, Quito, Ecuador.

MOEN DS AND WIENS JJ. 2008. Phylogenetic evidence for competitively divergence: body-size evolution in Caribbean treefrogs (Hylidae: Osteopilus). Evolution 63: $195-214$
MÜLLER J, SCHEYER TM, HEAD JJ, BARRET PM, WERNEBURG I, ERICSON PGP, POL D AND SÁNCHES-VILLAGRA. 2010. Homeotic effects, somitogenesis and the evolution of vertebral numbers in recent and fossil amniotes. P Natl Acad Sci USA 107(5): 2118-2123.

MYERS CW AND SCHARGEL WE. 2006. Morphological extreme-two new snakes of the genus Atractus from northwestern South America (Colubridae: Dipsadinae). Am Mus Novit 3535: 1-13.

NAGEL L AND SCHLUTER D. 1998. Body size, natural selection, and speciation in sticklebacks. Evolution 52: 209-218.

PASSOS P, AGUAYO R AND SCROCCHI G. 2009a. Rediscovery of the rare Atractus bocki, with assessment of the taxonomic status of $A$. canedii (Serpentes: Colubridae: Dipsadinae). J Herpetol 43(4): 701-715.

PASSOS P AND ARREDONDO JC. 2009. Rediscovery and redescription of the Andean earth-snake Atractus wagleri (Reptilia: Serpentes: Colubridae). Zootaxa 1969: 59-68.

PASSOS P, ARREDONDO JC, FERNANDES F AND LYNCH JD. 2009b. Three new Atractus (Serpentes: Colubridae) from Andes of Colombia. Copeia 2009(3): 425-436.

PASSOS P, CHIESSE A, TORRES-CARVAJAL O AND SAVAGE JM. 2010c. Testing species boundaries within Atractus occipitoalbus complex (Serpentes: Dipsadidae). Herpetologica 65(4): 384-403.

PASSOS P, CISNEROS-HEREDIA D, RIVERA DE, AGUILAR C AND SCHARGEL WE. 2012. Rediscovery of Atractus microrhynchus and reappraisal of the taxonomic status of $A$. emersoni and $A$. natans (Serpentes: Dipsadidae). Herpetologica 68: 375-392.

PASSOS P, CISNEROS-HEREDIA DF AND SALAZAR-V D. 2007a. Rediscovery and redescription of the rare Andean snake Atractus modestus. Herpetol J 17(1): 1-6.

PASSOS P, DOBIEY M AND VENEGAS PJ. $2010 \mathrm{a}$. Variation and natural history notes on giant groundsnakes, Atractus gigas (Serpentes: Dipsadidae). S Am J Hepetol 5: 73-82.

PASSOS P, ECHEVARRÍA LY AND VENEGAS PJ. 2013a. Morphological variation of Atractus carrioni (Serpentes: Dipsadidae). S Am J Herpetol 8: 109-120.

PASSOS P, FERNANDES DS AND BORGES-NOJOSA DM. 2007b. A new species of Atractus (Serpentes: Dipsadinae) from a relictual forest in Northeastern Brazil. Copeia 2007(4): 788-797.

PASSOS P AND FERNANDES R. 2008. A new species of colubrid snake genus Atractus (Reptilia: Serpentes) from central Amazon. Zootaxa 1849: 59-66.

PASSOS P, FERNANDES R, BÉRNILS RS AND MOURA-LEITE JC. 2010b. Taxonomic revision of the 
Brazilian Atlantic Forest Atractus (Reptilia: Serpentes: Dipsadidae). Zootaxa 2364: 1-63.

PASSOS P, FERNANDES R AND ZANELLA N. 2005. A new species of Atractus (Serpentes: Colubridae) from southern Brazil. Herpetologica 61(2): 209-218.

PASSOS P, FUENMAYOR GR AND BARRIO-AMORÓS C. 2009c. Description of two new species from Venezuela in the highly diverse dipsadine genus Atractus (Serpentes: Colubridae). Amphibia-Reptilia 30(2009): 233-243.

PASSOS P, KOK PJR, ALBUQUERQUE NR AND RIVAS G. 2013b. Groundsnakes of the Lost World: a review of Atractus (Serpentes: Dipsadidae) from the Pantepui region, northern South America. Herpetol Monogr 27: 52-86.

PASSOS P AND LYNCH JD. 2011. Revision of Atractus (Serpentes: Dipsadidae) from middle and upper Magdalena drainage of Colombia. 24 Herpetol Monogr 24: 149-173.

PASSOS P, LYNCH JD AND FERNANDES R. 2009d. Taxonomic status of Atractus sanctaemartae and $A$. nebularis, and description of a new species of Atractus from Atlantic coast of Colombia. Herpetol J 18(3): 175186.

PASSOS P, MARTINS A AND PINTO-COELHO D. 2016 a. Population morphological variation and natural history of Atractus potschi (Serpentes: Dipsadidae) in Northeastern Brazil. S Am J Hepetol 11: 188-211.

PASSOS P, MUESES-CISNEROS JJ, LYNCH JD AND FERNANDES R. 2009e. Pacific lowland Atractus (Serpentes: Dipsadidae), with description of three new species. Zootaxa 2293: 1-34.

PASSOS P AND PRUDENTE ALC. 2012. Morphological variation, polymorphism, and taxonomy of the Atractus torquatus complex (Serpentes: Dipsadidae). Zootaxa 3407: 1-21.

PASSOS P, MUESES-CISNEROS JJ, LYNCH JD AND FERNANDES R. 2009e. Pacific lowland Atractus (Serpentes: Dipsadidae), with description of three new species. Zootaxa 2293: 1-34.

xPASSOS P, RAMOS LO, FOUQUET A AND PRUDENTE ALC. 2017. Taxonomy, morphology, and distribution of Atractus flammigerus Boie, 1827 (Serpentes: Dipsadidae). Herpetologiga 73(4): 349-363.

PASSOS P, RAMOS LO, PINNA PH AND PRUDENTE ALC. 2013c. Morphological variation and putative phylogenetic affinities of the poorly known snake Atractus caxiuana (Serpentes: Dipsadidae). Zootaxa 3745: 35-48.

PASSOS P, TEIXEIRA-JUNIOR M, RECODER RS, DE SENA MA, DAL VECHIO F, PINTO HBA, MENDONÇA SHST, CASSIMIRO J AND RODRIGUES MT. 2013d. A new species of Atractus (Serpentes: Dipsadidae) from Serra do Cipó, Espinhaço range, Southeastern Brazil, with proposition of a new species group to the genus. Pap Avulsos Zool 53: 75-85.
PÉREZ-SANTOS C AND MORENO AG. 1990. Anotaciones biometricas y alimenticias de la serpiente neotropical Atractus badius (Boie, 1827) de la colección del Museo Nacional de Ciencias Naturales de Madrid. Rev Esp Herpetol 4: 9-15.

PERRELLA DF AND FRANCISCO MR. 2016. Atractus trihedrurus (South Brazilian Spindle Snake) Diet. Herpetol Rev 47(4): 676.

PETERS JA. 1964. Dictionary of herpetology. New York: Hafner Publishing, 426 p.

PETERS RH. 1983. The ecological implications of body size. Cambridge: Cambridge University Press, USA, 366 p.

PRUDENTE ALC AND PASSOS P. 2008. New species of Atractus Wagler (Serpentes: Dipsadinae) from Guyana Plateau in northern Brazil. J Herpetol 42(4): 723-732.

PRUDENTE ALC AND PASSOS P 2010. New cryptic species of Atractus (Serpentes: Dipsadidae) from Brazilian Amazonia. Copeia 2010(3): 397-404.

RAMOS LO. 2017. Morfologia comparada de representantes do gênero Atractus Wagler 1828 (Serpentes, Dipsadidae): novas aproximações baseadas na micro-ornamentação de escamas dorsais e osteologia craniana. PhD Thesis, Rio de Janeiro: Museu Nacional, Universidade Federal do Rio de Janeiro, 409 p.

SALAZAR-VALENZUELA D, TORRES-CARVAJAL O AND PASSOS P. 2014. A new species of Atractus (Serpentes: Dipsadidae) from Andes of Ecuador. Herpetologica 70: 350-373.

SAVAGE JM. 1960. A revision of the Ecuadorian snakes of the colubrid genus Atractus. Misc Publ Mus Zool Univ Michigan 112: 1-86.

SCANFERLA A. 2016. Postnatal ontogeny and evolution of macrostomy in snakes. R. Soc Open Sci 3: 160612.

SCHARGEL WE, LAMAR WW, PASSOS P, VALENCIA JH, CISNEROS-HEREDIA DF AND CAMPBELL JA. 2013. A new giant Atractus (Serpentes: Dipsadidae) from Ecuador, with notes on some other large Amazonian congeners. Zootaxa 3721: 455-474.

SCHLUTER D. 2000. The ecology of adaptive radiation. New York: Oxford University Press, 288 p.

VILELA B, VILLALOBOS F, RODRÍGUEZ MA AND TERRIBLE LC. 2014. Body size, extinction risk and knowledge bias in New World snakes. Plos One 9(11): e114329.

WOLTERING JM. 2012. From lizard to snake; behind the evolution of an extreme body Plan. Curr Genomics 13: 289-299.

ZAHER H, OLIVEIRA L, GRAZZIOTIN FG, CAMPAGNER M, JARED C, ANTONIAZZI MM AND PRUDENTE AL. 2014. Consuming viscous prey: a novel protein-secretin delivery system in neotropical snail-eating snakes. BMC Evol Biol 2014 14:28. 


\section{APPENDIX I}

\section{ADDITIONAL MATERIAL EXAMINED}

Countries are given in bold capitals, states in plain capitals, municipalities in italics, and localities in plain text.

Atractus gigas $(n=17)$ : $\mathrm{ECUADOR}$ :

CARCHI: Km 15 El Chical-Gualtal road, Tulcán Chical: (QCAZ 5771); COTOPAXI: Bosque Protector Río Guajalito (formerly Palmeras Farm), between San Francisco de Las Pampas and Quito: (FHGO 194, holotype; QCAZ 2099, topotype), Bosque Integral Otonga: (QCAZ 3266), San Francisco de Las Pampas: (QCAZ 175, 179, 443, 647, 662); PICHINCHA: Cantón San Miguel de los Bancos, Tadayapa road, Tandayapa Farm: (FHGO 4791), Chiriboga: (QCAZ 01), Reserva Las Gralarias: (MZUTI 3286), Las Palmas: Lloa: (DHMECN 372), Palmeras: (QCAZ 2099), Peñas Coloradas: (QCAZ 4058), Reserva Bella Vista: (QCAZ 6526); Provenance in error: Piso Tropical Oriental: without specific data: (MEPN 8706). PERU: CAJAMARCA: San Ignacio, Santuario Nacional Tabaconas Namballe: Alto Lhuama: (CORBIDI 877), El Chaupe: (ZFMK 89147). Atractus touzeti $(n=3)$ : ECUADOR: NAPO: Cordillera de los Guacamayos, CosangaArchidona road: (FHGO 517, holotype), La Virgen: (FHGO 2035-36, paratypes). 